\title{
Sorafenib enhances the in vitro anti-endothelial effects of low dose (metronomic) chemotherapy
}

\author{
ALEXANDRA MURRAY ${ }^{1,2^{*}}$, SAMANTHA J. LITTLE ${ }^{1 *}$, PAUL STANLEY ${ }^{2}$, \\ ANTHONY MARAVEYAS ${ }^{1,3,4}$ and LYNN CAWKWELL ${ }^{1,4}$ \\ ${ }^{1}$ Cancer Biology Proteomics Group, Postgraduate Medical Institute, University of Hull; \\ ${ }^{2}$ Plastic Surgery and ${ }^{3}$ Queens Centre for Oncology and Haematology, Castle Hill Hospital, \\ Hull and East Yorkshire NHS Trust; ${ }^{4}$ Hull York Medical School, Hull, UK
}

Received April 22, 2010; Accepted June 2, 2010

DOI: $10.3892 /$ or_00000954

\begin{abstract}
Angiogenesis inhibitors may enhance the effects of low dose (metronomic) chemotherapy. However, there is a wide range of novel angiogenesis inhibitors which must be tested in combinations with oral chemotherapy agents to assess the anti-endothelial and anti-cancer effects. This preliminary testing is most suited to high throughput in vitro models, rather than clinical trials. We aimed to establish an in vitro model and test the anti-endothelial and anti-cancer effects of the multi-kinase inhibitor sorafenib when used as a single agent and in combination with oral chemotherapy agents used at low concentrations. Micro-vascular endothelial cells and 3 cancer cell lines were utilised and an extended treatment strategy (96 h) was employed in order to mimic a continuous low dose anti-angiogenic chemotherapy regimen. Sorafenib significantly enhanced the anti-endothelial effect of low dose etoposide, paclitaxel and temozolomide. Sorafenib also significantly enhanced the anti-cancer effect of low dose etoposide, paclitaxel and temozolomide in SKMEL-2 melanoma cells, producing an additive effect on inhibition of cell growth in all cases. These combinations appear to be the most promising for in vivo pre-clinical studies, with a view to testing in melanoma patients as a continuous dosing strategy, due to the in vitro additive
\end{abstract}

Correspondence to: Dr Lynn Cawkwell, Research Laboratories, Daisy Building, Castle Hill Hospital, Hull, HU16 5JQ, UK

E-mail: 1.cawkwell@hull.ac.uk

${ }^{*}$ Contributed equally

Abbreviations: Cmax, peak plasma concentration; MVECs, human dermal microvascular endothelial cells; HUVECs, human umbilical vein endothelial cells; LDM, low dose metronomic; MTD, maximum tolerated dose; VEGFR, vascular endothelial growth factor receptor

Key words: angiogenesis inhibitors, endothelial cells, low dose chemotherapy, metronomic chemotherapy, sorafenib inhibitory effect on growth seen in both endothelial and cancer cells.

\section{Introduction}

Cancer therapy has traditionally focussed on achieving a cytotoxic effect. Combinations of agents have subsequently been employed in pursuit of the maximum possible cytotoxic effect. This is an empirical approach which is highlighted by the structure of conventional phase I-III trials, some of which include combination regimens. Combination regimens have traditionally been based on the avoidance of toxicities common to different agents and also on modest cancerspecific effects seen in the early stages of development of the drug. While the number of agents available in the early days of cancer treatment was slow to increase, this empirical approach remained unchallenged. However, the last decade has seen the emergence of multiple novel agents with potential anti-cancer effects. Only a small proportion of these have been developed as conventional non-specific cytotoxic chemotherapy agents and the majority have been developed as oral agents that are molecularly targeted. One of the most prolific areas within targeted agent development and testing has been that of angiogenesis inhibitors (1). Furthermore, some traditional cytotoxic chemotherapy agents, such as the microtubule-targeting taxanes, are now known to also have anti-angiogenic properties $(2,3)$.

The traditional 'maximum tolerated dose' (MTD) chemotherapy approach relies on the 'maximum dose for maximum efficacy' theory, but more often than not results in severe systemic side effects, development of tumour resistance and the requirement for long rest periods to allow patient recovery. These rest periods have since been shown to cause increased tumour angiogenesis, which is counter-productive in disease control (4-7). The conventional MTD scheduling of traditional cytotoxics is not necessary for an anti-angiogenic effect to be observed, and this has led to the investigation of continuous low dose 'metronomic' (LDM) anti-angiogenic chemotherapy schedules using an oral dose which is significantly lower than the MTD (8-12). The potential benefits of LDM oral chemotherapy over traditional MTD chemotherapy regimens include reduced systemic side effects, lower risk of drug 
Table I. Published phase I pharmacokinetic data for oral formulations of the drugs used in this study.

\begin{tabular}{|c|c|c|c|c|c|}
\hline Drug & $\begin{array}{c}\text { Published } \\
\operatorname{MTD}\left(\mathrm{mg} / \mathrm{m}^{2}\right)\end{array}$ & $\begin{array}{l}\text { Published Cmax } \\
\text { for MTD }\end{array}$ & Refs. $^{a}$ & $\begin{array}{c}\text { Equivalent molar } \\
\text { concentration of } \mathrm{Cmax}(\mu \mathrm{M})\end{array}$ & $\begin{array}{l}\text { In vitro dose range } \\
\text { selected }(\mu \mathrm{M})\end{array}$ \\
\hline $\begin{array}{l}\text { Temozolomide } \\
\text { (oral) } \\
\text { mol wt } 194.15\end{array}$ & 200 & $13.9 \mu \mathrm{g} / \mathrm{ml}$ & (29) & 71.5 & $0-50$ \\
\hline Paclitaxel (oral) & 300 & $0.33 \mu \mathrm{M}$ & (30) & 0.33 & $0-0.002$ \\
\hline $\begin{array}{l}\text { Vinorelbine (oral) } \\
\text { mol wt } 1079.12\end{array}$ & 80 & $133.4 \mathrm{ng} / \mathrm{ml}$ & (31) & 0.123 & $0-10$ \\
\hline $\begin{array}{l}\text { Etoposide (oral) } \\
\text { mol wt } 588.56\end{array}$ & 220 & $21.1 \mu \mathrm{g} / \mathrm{ml}$ & (32) & 35.8 & $0-5$ \\
\hline $\begin{array}{l}\text { Sorafenib (oral) } \\
\text { mol wt } 637\end{array}$ & $\begin{array}{l}400 \mathrm{mg} \\
\text { twice daily }\end{array}$ & $2.87 \mathrm{mg} / \mathrm{l}$ & (28) & 4.5 & $0-10$ \\
\hline
\end{tabular}

The Cmax data at the MTD was converted into an equivalent molar concentration and this was used to select an in vitro dose range. ${ }^{\text {Refs. }}$. refer to both Published MTD and Published Cmax for MTD.

resistance and decreased mobilisation of endothelial cells from bone-marrow which may otherwise induce tumour angiogenesis $(8,13,14)$.

There is compelling pre-clinical and clinical evidence to suggest that the anti-angiogenic effect of LDM chemotherapy can be enhanced with the combined administration of a molecularly-targeted angiogenesis inhibitor $(11,15-19)$. It is essential to identify oral-formulation chemotherapy agents which have an anti-angiogenic effect at LDM concentrations and to establish the optimal dose at which angiogenesis inhibition occurs $(9,20)$. Further, with the growing number of angiogenesis inhibitors there is a need for the development of predictive in vitro models to allow selection of the most promising anti-angiogenic combinations suitable for further clinical development. We aimed to establish an in vitro continuous dosing model and to assess the anti-cancer and antiendothelial effects of oral-formulation chemotherapy agents (temozolomide, paclitaxel, vinorelbine and etoposide) alone and when used at LDM concentrations in combination with sorafenib. Sorafenib (BAY 43-9006) is an oral small molecule multi-kinase inhibitor approved for use in advanced renal cell carcinoma and inoperable hepatocellular carcinoma $(21,22)$. It demonstrates anti-angiogenic and anti-proliferative effects through the inhibition of several receptor tyrosine kinases, including Raf kinase (thus inhibiting ERK signaling), vascular endothelial growth factor receptor (VEGFR)-1, VEGFR-2, VEGFR-3 and platelet-derived growth factor $B$ (23). Temozolomide is an alkylating agent descended from the antimelanoma compound dacarbazine (DTIC). It is a well-tolerated orally bio-available agent used in the treatment of gliomas and metastatic melanoma. Previous in vitro studies have demonstrated that LDM concentrations of temozolomide inhibit the proliferation of endothelial cells and inhibit angiogenesis $(17,24)$. Paclitaxel is an oral microtubule-targeting agent mostly used in the treatment of lung, ovarian and breast cancer. LDM concentrations of paclitaxel demonstrated antiproliferative effects in endothelial cells $(20,25)$ and synergised with cetuximab in the treatment of colon cancer xenografts (26). Vinorelbine is the first semi-synthetic vinca alkaloid, obtained from alkaloid extracts obtained from the rosy periwinkle. It gained approval to treat non-small cell lung cancer in 1991, and has since also been used in the treatment of breast and prostate cancer. An oral formulation was licensed for use in 2004, which has similar efficacy and safety profile to the intravenous form, and is therefore potentially suitable for LDM chemotherapy regimens. Etoposide phosphate is an inhibitor of the enzyme topoisomerase II. It is used in the treatment of Ewing's sarcoma, lung cancer, testicular cancer, leukaemias and lymphomas, and can be given in the oral or intravenous form, with comparable efficacy, making it an appropriate agent for use in an LDM anti-angiogenic chemotherapy approach. To assess the anti-endothelial effects of these compounds, human dermal microvascular endothelial cells (MVECs), which are VEGFR-2-positive, were selected for our in vitro model since endothelial cells from large vessels (such as human umbilical vein endothelial cells; HUVECs) may be less representative of the microvasculature (27). Three human cancer cell lines were utilised as controls to assess the anti-cancer effects of each agent.

\section{Materials and methods}

Drugs. Purified temozolomide was provided by ScheringPlough, UK. Paclitaxel (no.T7402), vinorelbine (no.V2264) and etoposide (no.E1383) were purchased from Sigma-Aldrich, UK. Purified sorafenib tosylat was provided by Bayer, USA. All drugs were reconstituted at $10 \mathrm{mM}$ in DMSO except for vinorelbine (reconstituted at $10 \mathrm{mM}$ in sterile water) and diluted in cell culture medium immediately prior to use.

Cells and culture conditions. MVECs (no.ZHK-2526) were purchased from TCS CellWorks, UK and maintained in Medium 199 (no.M4530, Sigma-Aldrich) supplemented with growth supplement and antibiotics (no.ZHS-8947, no.ZHR- 


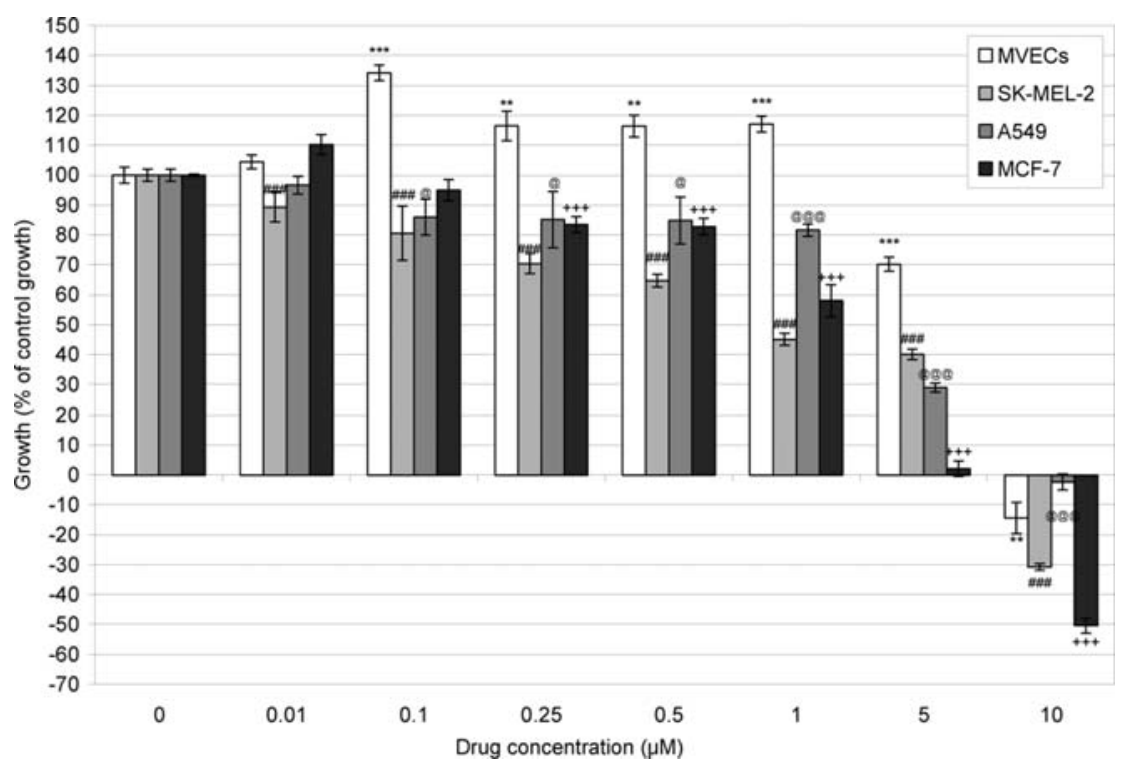

Figure 1. Effect of continuous $96 \mathrm{~h}$ exposure of sorafenib on in vitro cell proliferation using a dose range of 0-10 $\mu \mathrm{M}$. The growth of untreated control cells was taken as $100 \%$ and the growth of treated populations of cells was expressed as a percentage of this. Columns and error bars represent mean values \pm $\mathrm{SEM}$, respectively. Negative growth figures indicate that cell number after treatment was lower than cell number prior to treatment. Key: ${ }^{*} \mathrm{p}<0.05,{ }^{* *} \mathrm{p}<0.01$,

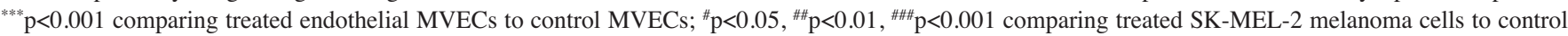
SK-MEL-2; ${ }^{\circledR} \mathrm{p}<0.05,{ }^{@ @} \mathrm{p}<0.01,{ }^{@ @ @ ~} \mathrm{p}<0.001$ comparing treated A549 lung cancer cells to control A549; ${ }^{+} \mathrm{p}<0.05,{ }^{++} \mathrm{p}<0.01,{ }^{+++} \mathrm{p}<0.001$ comparing treated MCF-7 breast cancer cells to control MCF-7. The clinical dose of sorafenib equates to $4.5 \mu \mathrm{M}$ (Table I). The lowest assayed dose of sorafenib which inhibited the growth of endothelial (MVEC) cells by $\sim 25 \%$ compared to control cell growth, at a highly significant $\mathrm{p}$-value (p<0.001), was $5 \mu \mathrm{M}$. At $5 \mu \mathrm{M}$ the growth of all 3 cancer cell lines was also significantly inhibited $(\mathrm{p}<0.001)$.

9939, TCS CellWorks) in tissue culture flasks pre-coated with gelatine (no.G6650, Sigma-Aldrich). MVECs were only used at passage 6 or below, as it is recognised that morphology and receptor status can alter with increasing passage. The human melanoma cell line SK-MEL-2 and human breast carcinoma cell line MCF-7 were purchased from the American Type Culture Collection. The human lung carcinoma cell line A549 was purchased from the European Collection of Cell Cultures. SK-MEL-2, MCF-7 and A549 cells were maintained in supplemented RPMI-1640 medium containing $10 \%(\mathrm{v} / \mathrm{v})$ foetal bovine serum.

Cell proliferation assay. In vitro chemosensitivity testing was performed on cells grown as a monolayer on 96-well flat-bottomed tissue culture plates. To allow an extended treatment duration of $96 \mathrm{~h}$ (modelled on the LDM chemotherapy rationale) for all experiments cells were seeded at a density of 3500 MVECs per well, 2000 SK-MEL-2 cells per well, 1500 MCF7 cells per well and 1000 A549 cells per well, each in $200 \mu \mathrm{l}$ of media. Each drug concentration was tested in sextuplicate. To determine the in vitro anti-proliferative effects of each drug all cells were treated daily over a 96-h total period using a clinically achievable dose range. For the traditional chemotherapy agents temozolomide, paclitaxel, vinorelbine and etoposide the dose range selected was biased towards an LDM concentration range. The dose range was determined using published pharmacokinetic data from phase I clinical trials which used the oral formulation of the drug at the MTD to determine a peak plasma concentration (Cmax). The Cmax values were converted where necessary to a molar concentration for in vitro use and the MTD, Cmax values and selected in vitro dose ranges are shown in Table I. The clinical dose of sorafenib was converted into a molar concentration and a wide dose range around this value was selected (Table I). In order to maintain a constant concentration of the drugs during in vitro culture, the cells were replenished with fresh media containing the appropriate drug concentrations on a daily basis as per Bocci et al (20). The concentration of DMSO vehicle in the media was $0.1 \%(\mathrm{v} / \mathrm{v})$ and this was used as a control in all experiments. Cells were allowed to attach to the wells for $24 \mathrm{~h}$ and then a standard MTT cell proliferation assay was performed immediately prior to drug addition (to determine the baseline number of viable cells) and again at the end of the period of drug treatment ( $96 \mathrm{~h}$ ). In brief, $20 \mu 1$ of MTT solution (no.M5655, Sigma-Aldrich) was added to each well containing $200 \mu 1$ of media, and the mixture incubated at $37^{\circ} \mathrm{C}$ for $4 \mathrm{~h}$. The liquid was then removed and $200 \mu \mathrm{l}$ of lysis buffer was added to each well and incubated for a further $2 \mathrm{~h}$. Optical density at $570 \mathrm{~nm}$ was read using a spectrophotometric plate reader. Cell growth from baseline was expressed as percentage change in absorbance values. To calculate the relative growth, the growth of control (untreated) cells was taken as $100 \%$, and the corresponding growth of treated populations of cells was expressed as a percentage of control growth.

Statistical analysis. All data represent the mean of three independent experiments and each drug concentration was tested in sextuplicate. The results of relative cell growth are expressed as mean values \pm standard error (SEM). The data was analysed using a two-sample t-test for populations of unequal variance to compare the effects of different drug doses and combinations. SPSS software version 14.0 (SPSS, Chicago, USA) was used for the statistical analysis. 


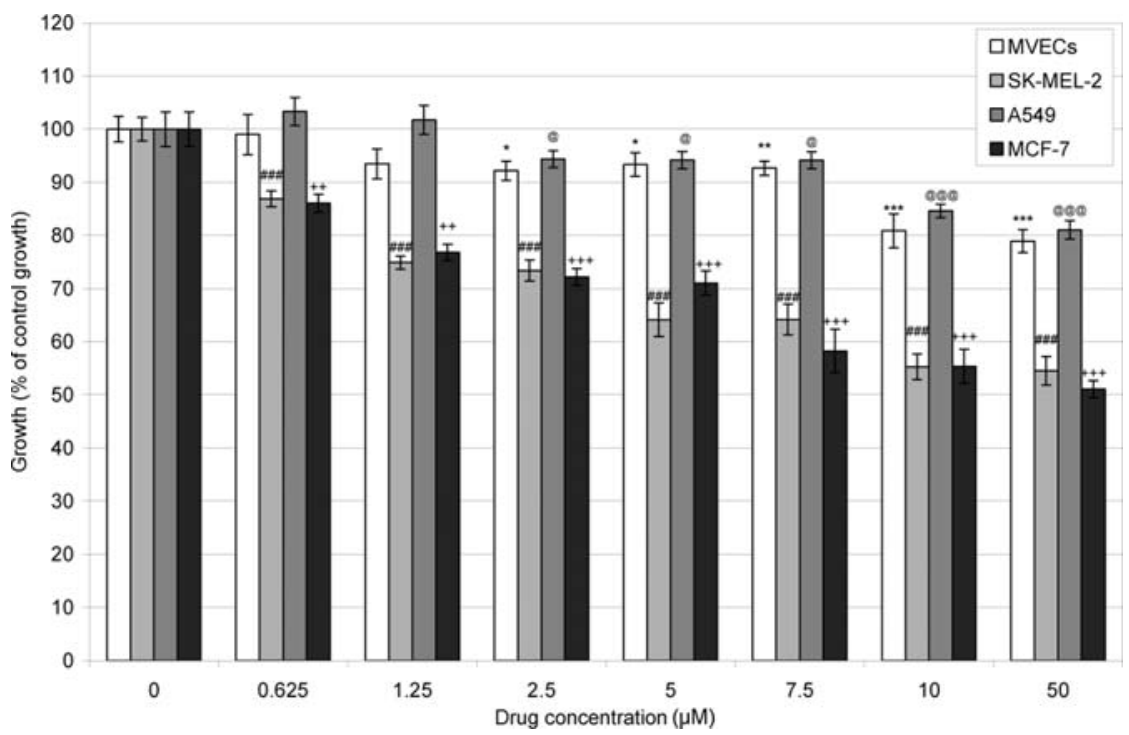

Figure 2. Effect of continuous $96 \mathrm{~h}$ exposure of temozolomide on in vitro cell proliferation using a dose range of 0-50 $\mu \mathrm{M}$. See legend in Fig. 1 for key. The MTD of temozolomide equates to $71.5 \mu \mathrm{M}$ (Table I). The lowest assayed dose of temozolomide which inhibited the growth of endothelial (MVEC) cells by $\sim 25 \%$ compared to control cell growth, at a highly significant $\mathrm{p}$-value ( $<0.001)$, was $10 \mu \mathrm{M}$. At $10 \mu \mathrm{M}$ the growth of all 3 cancer cell lines was also significantly inhibited $(\mathrm{p}<0.001)$.

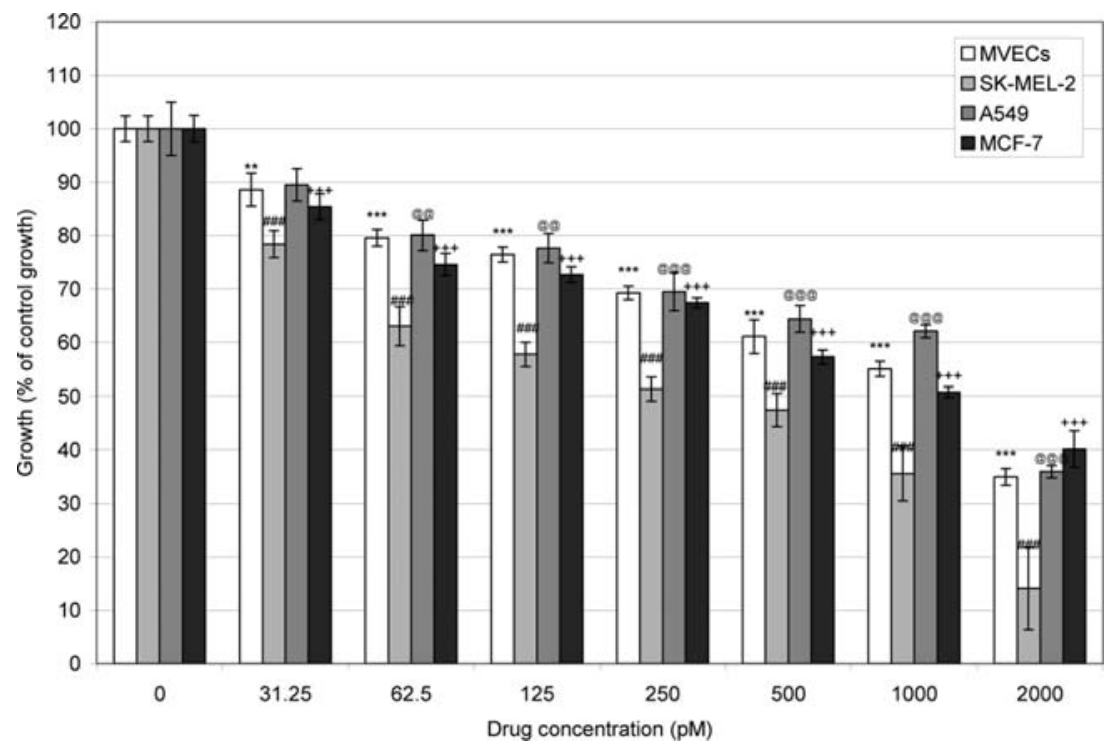

Figure 3. Effect of continuous $96 \mathrm{~h}$ exposure of paclitaxel on in vitro cell proliferation using a dose range of 0-2000 pM. See legend in Fig. 1 for key. The MTD of paclitaxel equates to $0.33 \mu \mathrm{M}$ (Table I). The lowest assayed dose of paclitaxel which inhibited the growth of endothelial (MVEC) cells by $\sim 25 \%$ compared to control cell growth, at a highly significant p-value ( $<<0.001)$, was $125 \mathrm{pM}$. At $125 \mathrm{pM}$ the growth of all 3 cancer cell lines was also inhibited ( $\mathrm{p}<0.001$ for SK-MEL-2 and MCF7; $\mathrm{p}<0.01$ for A549).

\section{Results}

The derived baseline control growth rates (untreated cells) of MVECs, MCF-7, A549 and SK-MEL-2 cells after $96 \mathrm{~h}$ were $101.02 \%( \pm 2.4), 98.36 \%( \pm 2.89), 108.02 \%( \pm 3.3)$ and $105.27 \%$ $( \pm 1.55)$, respectively. The percentage growth of the untreated cells after 4 days was normalized to $100 \%$, and the growth of treated cells was expressed as a percentage of this baseline growth.

Anti-proliferative effects of single agents. A clinically achievable dose range of each drug was assessed in a continuous dosing strategy over a $96-\mathrm{h}$ period to investigate the anti- proliferative effects on MVEC endothelial cells, SK-MEL-2 melanoma cells, MCF-7 breast carcinoma cells and A549 lung carcinoma cells. Fig. 1 shows the anti-proliferative activity of sorafenib. The lowest assayed dose of sorafenib which inhibited the growth of endothelial (MVEC) cells by $25 \%$ compared to control cell growth, at a highly significant $\mathrm{p}$-value ( $\mathrm{p}<0.001$ ), was $5 \mu \mathrm{M}$. At $5 \mu \mathrm{M}$ the growth of all 3 cancer cell lines was also significantly inhibited $(\mathrm{p}<0.001$; Fig. 1$)$. The clinical dose of sorafenib equates to $4.5 \mu \mathrm{M}$ (Table I) and we selected a dose of $5 \mu \mathrm{M}$ based on the MTT data for MVEC cells (Fig. 1) to use in further in vitro combination studies with the traditional cytotoxic agents. Fig. 2 shows the antiproliferative activity of temozolomide. The lowest assayed 


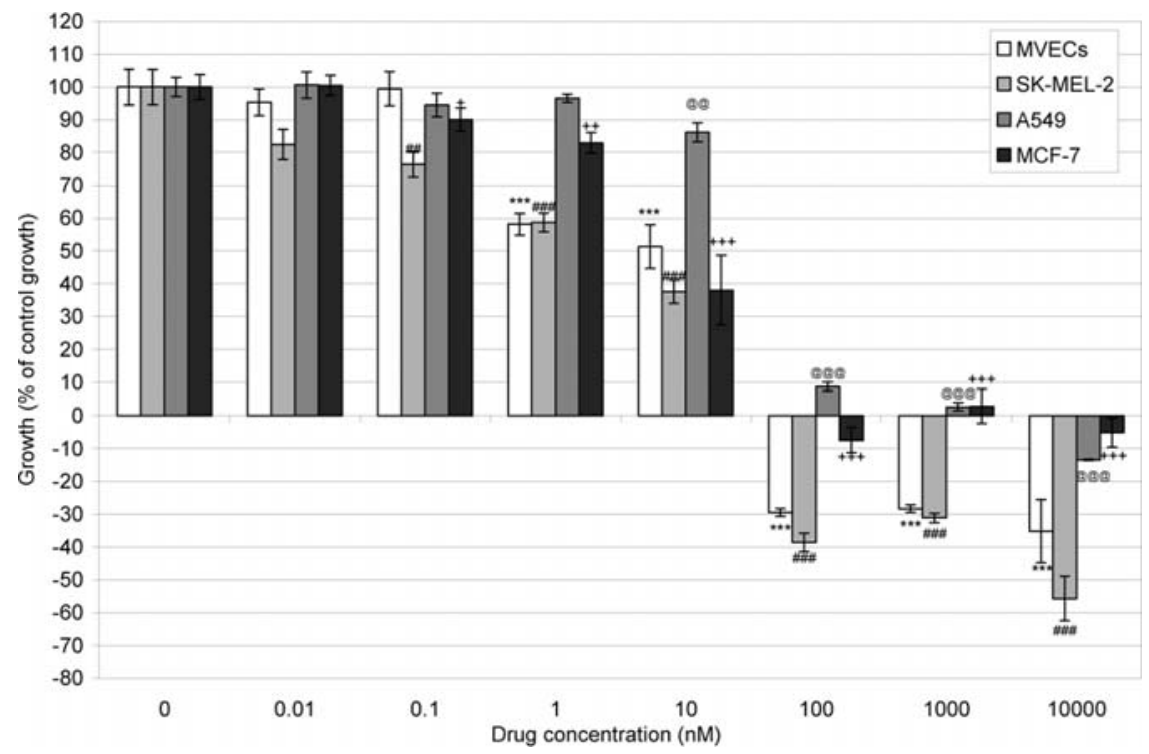

Figure 4. Effect of continuous $96 \mathrm{~h}$ exposure of vinorelbine on in vitro cell proliferation using a dose range of 0-10000 nM. See legend in Fig. 1 for key. The MTD of vinorelbine equates to $0.123 \mu \mathrm{M}$ (Table I). The lowest assayed dose of vinorelbine which inhibited the growth of endothelial (MVEC) cells by $25 \%$ compared to control cell growth, at a highly significant p-value ( $<<0.001)$, was $1 \mathrm{nM}$. At $1 \mathrm{nM}$ the growth of SK-MEL-2 and MCF-7 cells was inhibited $(\mathrm{p}<0.001$ SK-MEL-2; $<<0.01$ for MCF-7), however, no significant effect was seen with A549 cells at this dose.

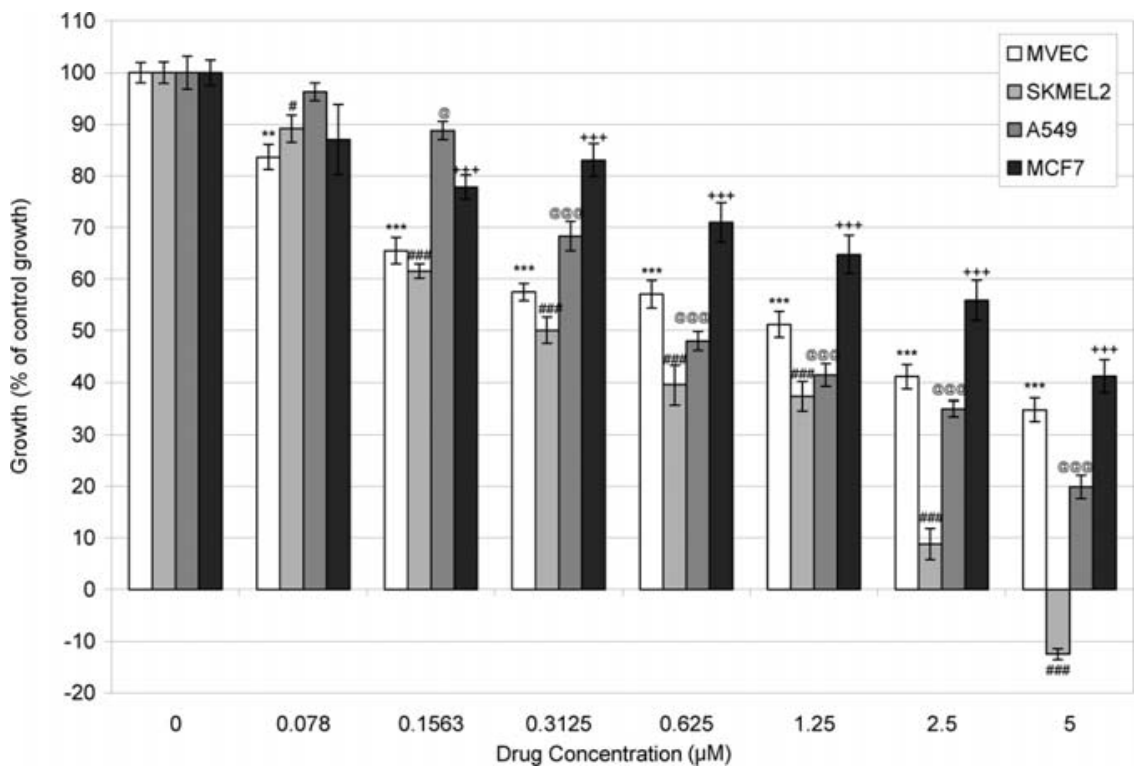

Figure 5. Effect of continuous $96 \mathrm{~h}$ exposure of etoposide on in vitro cell proliferation using a dose range of 0-5 $\mu \mathrm{M}$. See legend in Fig. 1 for key. The MTD of etoposide equates to $35.8 \mu \mathrm{M}$ (Table I). The lowest assayed dose of etoposide which inhibited the growth of endothelial (MVEC) cells by $\sim 25 \%$ compared to control cell growth, at a highly significant $\mathrm{p}$-value ( $<<0.001$ ), was $0.16 \mu \mathrm{M}$. At $0.16 \mu \mathrm{M}$ the growth of all 3 cancer cell lines was also inhibited ( $<<0.001$ for SK-MEL-2 and MCF-7; $<<0.05$ for A549).

dose of temozolomide which inhibited the growth of endothelial (MVEC) cells by $\sim 25 \%$ compared to control cell growth, at a highly significant $\mathrm{p}$-value $(\mathrm{p}<0.001)$, was $10 \mu \mathrm{M}$. At $10 \mu \mathrm{M}$ the growth of all 3 cancer cell lines was also significantly inhibited ( $\mathrm{p}<0.001$; Fig. 2). The MTD of temozolomide equates to $71.5 \mu \mathrm{M}$ (Table I) and we selected a dose of $10 \mu \mathrm{M}$ (13.9\% of MTD) based on the MTT data for MVEC cells (Fig. 2) to use in an in vitro LDM dosing strategy in combination with sorafenib. Fig. 3 shows the anti-proliferative activity of paclitaxel. The lowest assayed dose of paclitaxel which inhibited the growth of endothelial (MVEC) cells by $\sim 25 \%$ compared to control cell growth, at a highly significant p-value $(\mathrm{p}<0.001)$, was $125 \mathrm{pM}$. At $125 \mathrm{pM}$ the growth of all 3 cancer cell lines was also inhibited ( $<<0.001$ for SK-MEL-2 and MCF-7; $\mathrm{p}<0.01$ for A549; Fig. 3). The MTD of paclitaxel equates to $0.33 \mu \mathrm{M}$ (Table I) and we selected a dose of $125 \mathrm{pM}$ $(0.03 \%$ of MTD) based on the MTT data for MVEC cells (Fig. 3) to use in an in vitro LDM dosing strategy in combination with sorafenib. Fig. 4 shows the anti-proliferative activity of vinorelbine. The lowest assayed dose of vinorelbine which inhibited the growth of endothelial (MVEC) cells by $\sim 25 \%$ compared to control cell growth, at a highly significant 


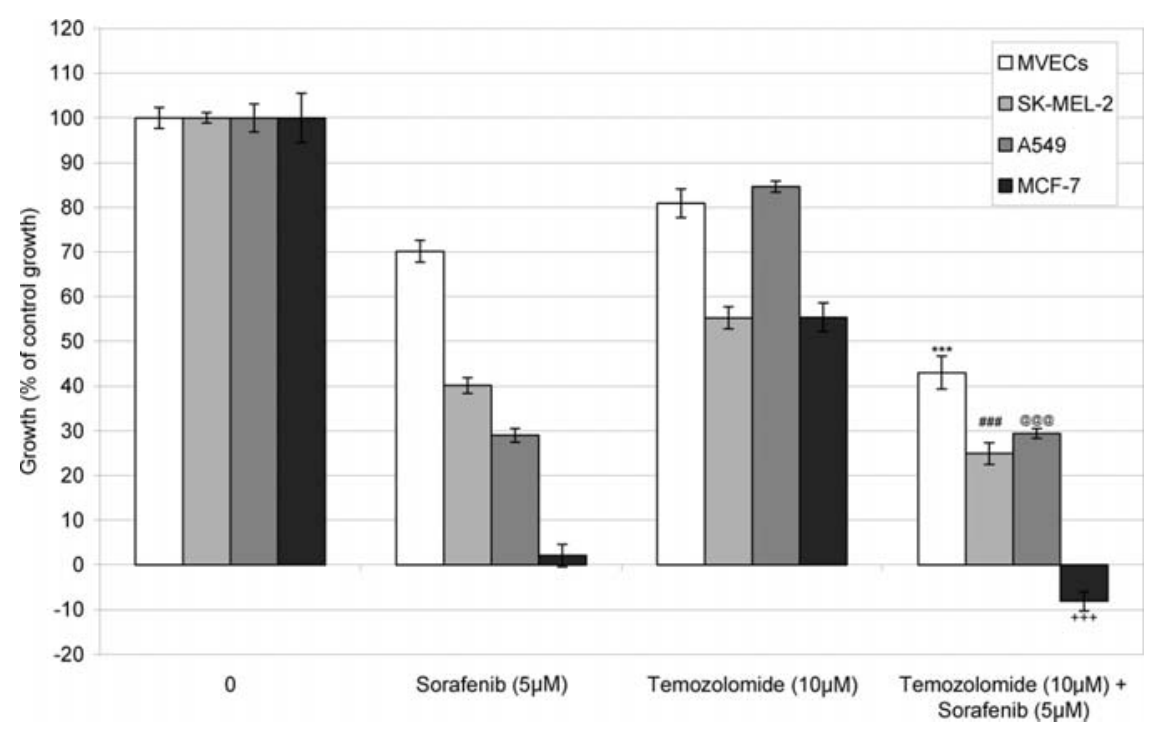

Figure 6. Effect of $5 \mu \mathrm{M}$ sorafenib in combination with low dose temozolomide $(10 \mu \mathrm{M})$ on in vitro MVEC and cancer cell growth compared with single drug schedule following continuous $96 \mathrm{~h}$ exposure. The growth of untreated control cells was taken as $100 \%$ and the growth of treated populations of cells was expressed as a percentage of this. Columns and bars represent mean values \pm SEM respectively. Negative growth figures indicate that cell number after treatment was lower than cell number prior to treatment. Key: ${ }^{* * *} \mathrm{p}<0.001$ comparing combinational regime to single chemotherapeutic drug schedule (MVECs);

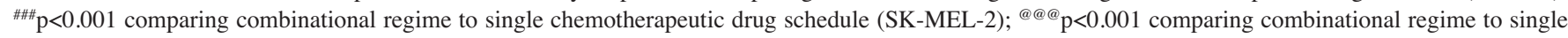
chemotherapeutic drug schedule (A549); ${ }^{++} \mathrm{p}<0.001$ comparing combinational regime to single chemotherapeutic drug schedule (MCF-7).

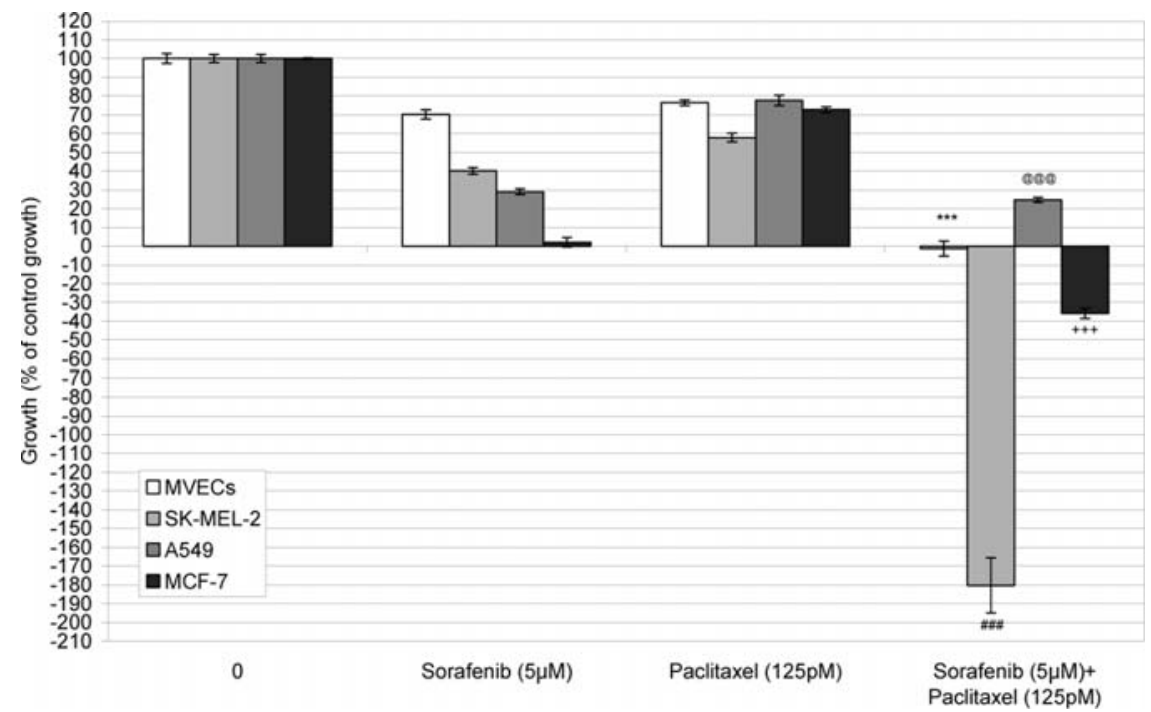

Figure 7. Effect of $5 \mu \mathrm{M}$ sorafenib in combination with low dose paclitaxel (125 pM) on in vitro MVEC and cancer cell growth compared with single drug schedule following continuous $96 \mathrm{~h}$ exposure. See legend in Fig. 6 for key.

p-value $(\mathrm{p}<0.001)$, was $1 \mathrm{nM}$. At $1 \mathrm{nM}$ the growth of SKMEL-2 and MCF-7 cells was inhibited ( $<<0.001$ SK-MEL-2; $\mathrm{p}<0.01$ for $\mathrm{MCF}-7$ ); however, no significant effect was seen with A549 cells at this dose. The MTD of vinorelbine equates to $0.123 \mu \mathrm{M}$ (Table I) and we selected a dose of $1 \mathrm{nM}(0.8 \%$ of MTD) based on the MTT data for MVEC cells (Fig. 4) to use in an in vitro LDM dosing strategy in combination with sorafenib. Fig. 5 shows the anti-proliferative activity of etoposide. The lowest assayed dose of etoposide which inhibited the growth of endothelial (MVEC) cells by $25 \%$ compared to control cell growth, at a highly significant $\mathrm{p}$-value $(\mathrm{p}<0.001)$, was $0.16 \mu \mathrm{M}$. At $0.16 \mu \mathrm{M}$ the growth of all 3 cancer cell lines was also inhibited $(\mathrm{p}<0.001$ for SK-MEL-2 and MCF-7; $\mathrm{p}<0.05$ for A549). The MTD of etoposide equates to $35.8 \mu \mathrm{M}$ (Table I) and we selected a dose of $0.16 \mu \mathrm{M}$ ( $0.4 \%$ of MTD) based on the MTT data for MVEC cells (Fig. 5) to use in an in vitro LDM dosing strategy in combination with sorafenib.

Anti-proliferative effects of low dose chemotherapy when combined with sorafenib. A low dose metronomic concentration was selected for each chemotherapeutic agent as described above and each drug was assayed in combination with $5 \mu \mathrm{M}$ sorafenib in order to determine whether sorafenib could enhance the effects of single agent chemotherapy. A dose of $5 \mu \mathrm{M}$ sorafenib was selected for the combination 


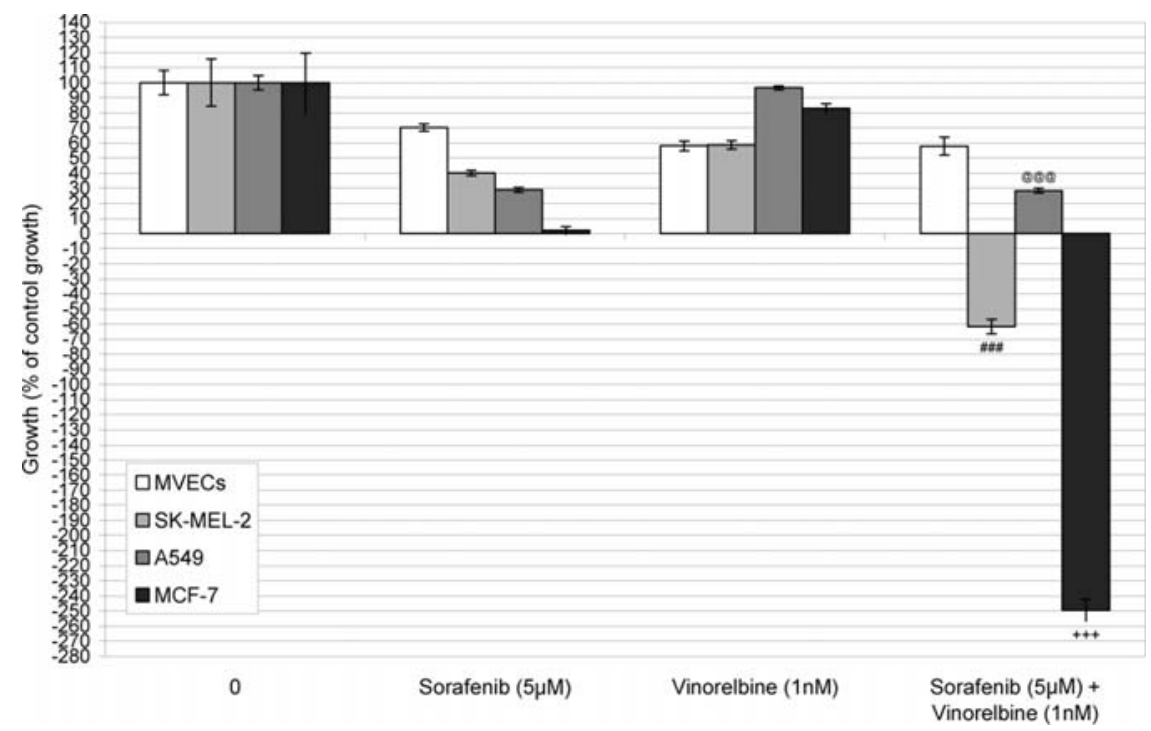

Figure 8. Effect of $5 \mu \mathrm{M}$ sorafenib in combination with low dose vinorelbine (1 nM) on in vitro MVEC and cancer cell growth compared with single drug schedule following continuous $96 \mathrm{~h}$ exposure. See legend in Fig. 6 for key.

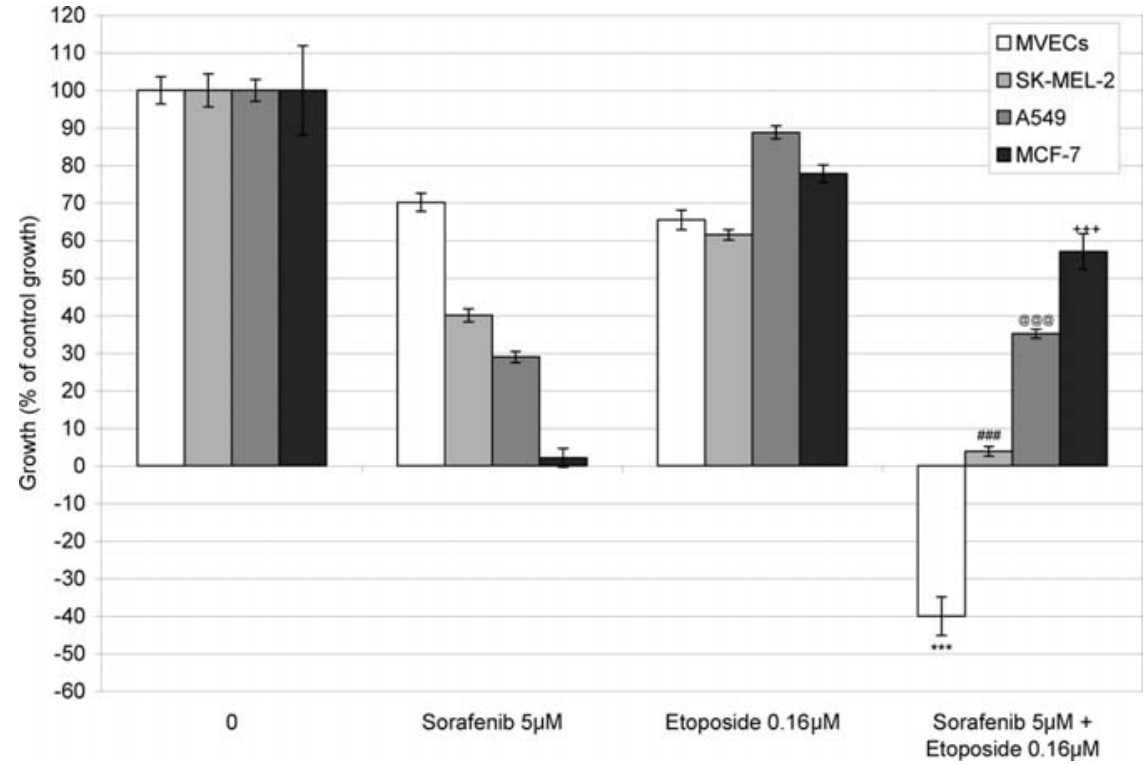

Figure 9. Effect of $5 \mu \mathrm{M}$ sorafenib in combination with low dose etoposide $(0.16 \mu \mathrm{M})$ on in vitro MVEC and cancer cell growth compared with single drug schedule following continuous $96 \mathrm{~h}$ exposure. See legend in Fig. 6 for key.

studies since significant inhibition of endothelial cells (MVECs) was seen when used as a single agent (Fig. 1) and this also approximates to the clinical dose. The results for each combination are shown in Figs. 6-9 and the summary of data for each cell line is shown in Tables II-V. In endothelial cells (MVECs) sorafenib significantly enhanced the anti-endothelial effects of low dose etoposide, paclitaxel and temozolomide $(\mathrm{p}<0.001)$, but did not enhance the effect of vinorelbine (Table II). In SK-MEL-2 melanoma cells sorafenib significantly enhanced the anti-cancer effect of low dose paclitaxel, vinorelbine, etoposide and temozolomide ( $\mathrm{p}<0.001$; Table III). In A549 lung cancer cells sorafenib significantly enhanced the anti-cancer effect of low dose paclitaxel, vinorelbine, etoposide and temozolomide $(\mathrm{p}<0.001)$; however, the level of effect for all combinations was equivalent to that induced by $5 \mu \mathrm{M}$ sorafenib alone (Table IV). In MCF-7 breast cancer cells sorafenib significantly enhanced the anti-cancer effect of low dose vinorelbine, paclitaxel and temozolomide $(p<0.001)$; however, the level of effect for the temozolomide/ sorafenib combination was almost equivalent to that induced by $5 \mu \mathrm{M}$ sorafenib alone (Table $\mathrm{V}$ ). Sorafenib significantly enhanced the anti-cancer effect of low dose etoposide in MCF7 cells; however, the level of effect for the etoposide/ sorafenib combination did not approach that induced by $5 \mu \mathrm{M}$ sorafenib alone (Table V).

\section{Discussion}

There is evidence that targeted angiogenesis inhibitors may enhance the effects of LDM chemotherapy (11,15-19). 
Table II. Effect of $5 \mu \mathrm{M}$ sorafenib on the anti-endothelial activity of low dose chemotherapy in MVEC endothelial cells.

\begin{tabular}{lcccc}
\hline MVECs & $\begin{array}{c}\text { Temozolomide } \\
10 \mu \mathrm{M} \mathrm{[80 \% ]}\end{array}$ & $\begin{array}{c}\text { Paclitaxel } \\
125 \mathrm{pM} \mathrm{[76 \% ]}\end{array}$ & $\begin{array}{c}\text { Vinorelbine } \\
1 \mathrm{nM}[58 \%]\end{array}$ & $\begin{array}{c}\text { Etoposide } \\
0.16 \mu \mathrm{M}[65 \%]\end{array}$ \\
\hline $\begin{array}{l}\text { Sorafenib } \\
5 \mu \mathrm{M}[70 \%]\end{array}$ & $\mathbf{4 3 \%}$ & $\mathbf{- 1 \%}$ & $58 \%$ & $\mathbf{- 4 0 \%}$ \\
\hline
\end{tabular}

Values represent $\%$ growth compared with control cells. Single agent data is given in square brackets. For drug combinations, significant differences $(p<0.001)$ to single agent chemotherapy data are shown in bold. Sorafenib significantly enhanced the anti-endothelial effect of low dose etoposide, paclitaxel and temozolomide in MVECs $(\mathrm{p}<0.001)$. Sorafenib did not enhance the effect of low dose single agent vinorelbine.

Table III. Effect of $5 \mu \mathrm{M}$ sorafenib on the efficacy of low dose chemotherapy in SK-MEL-2 melanoma cells.

\begin{tabular}{lcccc}
\hline & Temozolomide & Paclitaxel & Vinorelbine & Etoposide \\
$10 \mu \mathrm{M}[55 \%]$ & $125 \mathrm{pM}[58 \%]$ & $\mathrm{nM}[58 \%]$ & $0.16 \mu \mathrm{M}[61 \%]$ \\
\hline $\begin{array}{l}\text { Sorafenib } \\
5 \mu \mathrm{M}[40 \%]\end{array}$ & $\mathbf{2 4 \%}$ & $\mathbf{- 1 8 0 \%}$ & $\mathbf{- 6 1 \%}$ & $\mathbf{3} \%$ \\
\hline
\end{tabular}

Values represent $\%$ growth compared with control cells. Single agent data is given in square brackets. For drug combinations, significant differences $(\mathrm{p}<0.001)$ to single agent chemotherapy data are shown in bold. Sorafenib significantly enhanced the anti-cancer effect of low dose paclitaxel, vinorelbine, etoposide and temozolomide in SK-MEL-2 cells $(\mathrm{p}<0.001)$.

Table IV. Effect of $5 \mu \mathrm{M}$ sorafenib on the efficacy of low dose chemotherapy in A549 lung cancer cells.

\begin{tabular}{lcccc}
\hline A549 & $\begin{array}{c}\text { Temozolomide } \\
10 \mu \mathrm{M}[85 \%]\end{array}$ & $\begin{array}{c}\text { Paclitaxel } \\
125 \mathrm{pM}[78 \%]\end{array}$ & $\begin{array}{c}\text { Vinorelbine } \\
1 \mathrm{nM}[97 \%]\end{array}$ & $0.16 \mu \mathrm{M}[88 \%]$ \\
\hline $\begin{array}{l}\text { Sorafenib } \\
5 \mu \mathrm{M}[29 \%]\end{array}$ & $\mathbf{2 9} \%$ & $\mathbf{2 5} \%$ & $\mathbf{2 9 \%}$ & $\mathbf{3 5 \%}$ \\
\hline
\end{tabular}

Values represent $\%$ growth compared with control cells. Single agent data is given in square brackets. For drug combinations, significant differences $(p<0.001)$ to single agent chemotherapy data are shown in bold. Sorafenib significantly enhanced the anti-cancer effect of low dose paclitaxel, vinorelbine, etoposide and temozolomide in A549 cells $(\mathrm{p}<0.001)$; however, the level of effect for all combinations was equivalent to that induced by $5 \mu \mathrm{M}$ sorafenib alone.

Table V. Effect of $5 \mu \mathrm{M}$ sorafenib on the efficacy of low dose chemotherapy in MCF-7 breast cancer cells.

\begin{tabular}{lcccc}
\hline & Temozolomide & Paclitaxel & Einorelbine & Etoposide \\
$10 \mu \mathrm{M}[55 \%]$ & $125 \mathrm{pM}[72 \%]$ & $\mathrm{nM}[82 \%]$ & $0.16 \mu \mathrm{M}[77 \%]$ \\
\hline $\begin{array}{l}\text { Sorafenib } \\
5 \mu \mathrm{M}[2 \%]\end{array}$ & $\mathbf{- 8} \%$ & $\mathbf{- 3 5} \%$ & $\mathbf{- 2 4 9} \%$ & $\mathbf{5 8} \%$ \\
\hline
\end{tabular}

Values represent $\%$ growth compared with control cells. Single agent data is given in square brackets. For drug combinations, significant differences $(p<0.001)$ to single agent chemotherapy data are shown in bold. Sorafenib significantly enhanced the anti-cancer effect of low dose vinorelbine, paclitaxel and temozolomide in MCF-7 cells $(\mathrm{p}<0.001)$; however, the level of effect for the temozolomide/sorafenib combination was almost equivalent to that induced by $5 \mu \mathrm{M}$ sorafenib alone. Sorafenib significantly enhanced the anti-cancer effect of low dose etoposide; however, the level of effect for the etoposide/sorafenib combination did not approach that induced by $5 \mu \mathrm{M}$ sorafenib alone. 
However, there is a wide range of novel angiogenesis inhibitors which must be tested in combinations with oral chemotherapy agents to assess the anti-endothelial and anticancer effects. This preliminary testing is most suited to high throughput in vitro models, rather than clinical trials. The most promising additive combinations and dosing strategy can then be selected from the in vitro data and this information used in the design of pre-clinical or clinical trials. We, therefore, aimed to establish an in vitro model to test the antiendothelial and anti-cancer effects of the multi-kinase inhibitor sorafenib when used as a single agent and in combination with traditional oral chemotherapy agents used at LDM concentrations. Microvascular endothelial cells were utilised in the model to approximate to the human microvasculature and an extended treatment strategy (96 h) was used in order to mimic an LDM anti-angiogenic chemotherapy regimen.

Each drug was assayed in a clinically achievable dose range, which was determined from phase I pharmacokinetic data. The oral dose for sorafenib, derived from phase I trials, is $400 \mathrm{mg}$ twice daily giving a peak plasma concentration of $2.87 \mathrm{mg} / 1$ (28). This is equivalent to $4.5 \mu \mathrm{M}$ and, as shown by our in vitro data, a similar dose $(5 \mu \mathrm{M})$ induced a significant anti-endothelial effect in our MVEC cell model. Sorafenib $(5 \mu \mathrm{M})$ also demonstrated significant anti-cancer effects on all 3 cancer cell lines tested.

Assessing our initial MTT data for the MVECs allowed us to select, for each chemotherapy agent, a low dose where a significant anti-endothelial effect was demonstrated. We selected doses of $10 \mu \mathrm{M}$ temozolomide (13.9\% of MTD), $125 \mathrm{pM}$ paclitaxel ( $0.03 \%$ of MTD), $1 \mathrm{nM}$ vinorelbine $(0.8 \%$ of MTD) and $0.16 \mu \mathrm{M}$ etoposide ( $0.4 \%$ of MTD) based on the MTT data for MVEC cells. We have previously demonstrated that similar low doses of paclitaxel and temozolomide have an anti-endothelial effect on HUVECs (17). Low dose paclitaxel has also previously been demonstrated to inhibit endothelial cells at picomolar concentrations $(2,25)$. The selected doses were then tested in combination with $5 \mu \mathrm{M}$ sorafenib in the extended dosing model to identify whether sorafenib could enhance the anti-endothelial and anti-cancer effects of any of the chemotherapy agents in an additive manner. Sorafenib $(5 \mu \mathrm{M})$ significantly enhanced the antiendothelial effect of low dose etoposide $(0.16 \mu \mathrm{M})$, paclitaxel $(125 \mathrm{pM})$ and temozolomide $(10 \mu \mathrm{M})$ as demonstrated in MVECs. Sorafenib also enhanced the anti-cancer effect of these traditional chemotherapy agents when used at low doses, as demonstrated in the cancer cell lines. Sorafenib $(5 \mu \mathrm{M})$ significantly enhanced the anti-cancer effect of low dose etoposide $(0.16 \mu \mathrm{M})$, paclitaxel $(125 \mathrm{pM})$ and temozolomide $(10 \mu \mathrm{M})$ in SK-MEL-2 melanoma cells, producing an additive effect on inhibition of cell growth in all cases. These combinations appear to be the most promising for in vivo pre-clinical studies, with a view to testing in melanoma patients as a continuous dosing strategy, due to the in vitro additive inhibitory effect on growth seen in both endothelial and cancer cells. In addition, sorafenib $(5 \mu \mathrm{M})$ significantly enhanced the anti-cancer effect of low dose paclitaxel (125 pM) in MCF-7 breast cancer cells, producing an additive effect on inhibition of cell growth. This combination would appear to be the most promising for in vivo pre-clinical studies, with a view to testing in a continuous dosing strategy in breast cancer patients, due to the in vitro additive inhibitory effect on growth seen in both endothelial and cancer cells.

The current rationale for the design of combination regimens is empirical and the underlying mechanisms of action of such combinations and their synergistic action are poorly understood. In this potentially confusing era of multi-targeted combinational therapy, new agents are continuously being developed. Oncologists require a framework or at least a justifiable starting point, to select drug combinations and doses to take forward into clinical trials of all malignancies. Although in vitro work will never fully translate to human studies, here we demonstrate a logical approach using clinically relevant agents at achievable doses and in relevant combinations. Our in vitro model has identified statistically significant anti-endothelial and anti-cancer effects produced by several novel combinations of sorafenib with low dose chemotherapy. The agents used are already available in oral form and at these low doses, side effects should be minimal. Continuous low dose therapy, compared to a high bolusdosing approach, could potentially improve both quality of life and disease-control for cancer patients.

\section{Acknowledgements}

This study was supported in parts by Yorkshire Cancer Research and small grants from the Peel Medical Research Trust. The funders had no role in the study design; in the collection, analysis and interpretation of data; in the writing of the manuscript; or the decision to submit the manuscript for publication. Mr. Vicknesh Sreetharan assisted with the MTT assays.

\section{References}

1. Le Tourneau C, Faivre S and Raymond E: New developments in multitargeted therapy for patients with solid tumours. Cancer Treat Rev 34: 37-48, 2008.

2. Belotti D, Vergani V, Drudis T, Borsotti P, Pitelli MR, Viale G, Giavazzi $\mathrm{R}$ and Taraboletti G: The microtubule-affecting drug paclitaxel has anti-angiogenic activity. Clin Cancer Res 2: 1843-1849, 1996.

3. Pasquier E, André N and Braguer D: Targeting microtubules to inhibit angiogenesis and disrupt tumour vasculature: implications for cancer treatment. Curr Cancer Drug Targets 7: 566-581, 2007.

4. Stoelting S, Trefzer T, Kisro J, Steinke A, Wagner T and Peters SO: Low-dose oral metronomic chemotherapy prevents mobilization of endothelial progenitor cells into the blood of cancer patients. In Vivo 22: 831-836, 2008.

5. Browder T, Butterfield CE, Kräling BM, Shi B, Marshall B, O'Reilly MS and Folkman J: Antiangiogenic scheduling of chemotherapy improves efficacy against experimental drugresistant cancer. Cancer Res 60: 1878-1886, 2000

6. Ma J and Waxman DJ: Combination of antiangiogenesis with chemotherapy for more effective cancer treatment. Mol Cancer Ther 7: 3670-3684, 2008.

7. Shaked Y and Kerbel RS: Antiangiogenic strategies on defense: on the possibility of blocking rebounds by the tumor vasculature after chemotherapy. Cancer Res 67: 7055-7058, 2007.

8. Kerbel RS and Kamen BA: The anti-angiogenic basis of metronomic chemotherapy. Nat Rev Cancer 4: 423-436, 2004.

9. Lam T, Hetherington JW, Greenman J and Maraveyas A: From total empiricism to a rational design of metronomic chemotherapy phase I dosing trials. Anticancer Drugs 17: 113-121, 2006.

10. Pasquier E, Honoré S and Braguer D: Microtubule-targeting agents in angiogenesis: where do we stand? Drug Resist Updat 9: 74-86, 2006. 
11. Bocci G, Falcone A, Fioravanti A, Orlandi P, Di Paolo A, Fanelli G, Viacava P, Naccarato AG, Kerbel RS, Danesi R, De Tacca M and Allegrini G: Antiangiogenic and anticolorectal cancer effects of metronomic irinotecan chemotherapy alone and in combination with semaxinib. Br J Cancer 98: 1619-1629, 2008.

12. Munoz R, Man S, Shaked Y, Lee CR, Wong J, Francia G and Kerbel RS: Highly efficacious non-toxic preclinical treatment for advanced metastatic breast cancer using combination oral UFT-cyclophosphamide metronomic chemotherapy. Cancer Res 66: 3386-3391, 2006.

13. Scharovsky OG, Mainetti LE and Rozados VR: Metronomic chemotherapy: changing the paradigm that more is better. Curr Oncol 16: 7-15, 2009

14. Gasparini G: Metronomic scheduling: the future of chemotherapy? Lancet Oncol 2: 733-740, 2001.

15. Blansfield JA, Caragacianu D, Alexander HR III, Tangrea MA, Morita SY, Lorang D, Schafer P, Muller G, Stirling D, Royal RE and Libutti SK: Combining agents that target the tumor microenvironment improves the efficacy of anticancer therapy. Clin Cancer Res 14: 270-280, 2008.

16. Ma J and Waxman DJ: Modulation of the antitumor activity of metronomic cyclophosphamide by the angiogenesis inhibitor axitinib. Mol Cancer Ther 7: 79-89, 2008.

17. Lam T, Hetherington JW, Greenman J, Little S and Maraveyas A: Metronomic chemotherapy dosing-schedules with estramustine and temozolomide act synergistically with anti-VEGFR-2 antibody to cause inhibition of human umbilical venous endothelial cell growth. Acta Oncol 46: 1169-1177, 2007.

18. Dellapasqua S, Bertolini F, Bagnardi V, Campagnoli E, Scarano E, Torrisi R, Shaked Y, Mancuso P, Goldhirsch A Rocca A, Pietri E and Colleoni M: Metronomic cyclophosphamide and capecitabine combined with bevacizumab in advanced breast cancer. J Clin Oncol 26: 4899-4905, 2008.

19. Garcia AA, Hirte H, Fleming G, Yang D, Tsao-Wei DD, Roman L, Groshen S, Swenson S, Markland F, Gandara D, Scudder S, Morgan R, Chen H, Lenz HJ and Oza AM: Phase II clinical trial of bevacizumab and low-dose metronomic oral cyclophosphamide in recurrent ovarian cancer: a trial of the California, Chicago and Princess Margaret Hospital phase II consortia. J Clin Oncol 26: 76-82, 2008.

20. Bocci G, Nicolaou KC and Kerbel RS: Protracted low-dose effects on human endothelial cell proliferation and survival in vitro reveal a selective antiangiogenic window for various chemotherapeutic drugs. Cancer Res 62: 6938-6943, 2002.

21. Kane RC, Farrell AT, Saber H, Tang S, Williams G, Jee JM, Liang C, Booth B, Chidambaram N, Morse D, Sridhara R, Garvey P, Justice R and Pazdur R: Sorafenib for the treatment of advanced renal cell carcinoma. Clin Cancer Res 12: 7271-7278, 2006 .
22. Kane RC, Farrell AT, Madabushi R, Booth B, Chattopadhyay S, Sridhara R, Justice R and Pazdur R: Sorafenib for the treatment of unresectable hepatocellular carcinoma. Oncologist 14: 95-100, 2009.

23. Wilhelm SM, Adnane L, Newell P, Villanueva A, Llovet JM and Lynch M: Preclinical overview of sorafenib, a multikinase inhibitor that targets both Raf and VEGF and PDGF receptor tyrosine kinase signaling. Mol Cancer Ther 7: 3129-3140, 2008.

24. Kurzen H, Schmitt S, Naher H and Mohler T: Inhibition of angiogenesis by non-toxic doses of temozolomide. Anticancer Drugs 14: 515-522, 2003.

25. Wang J, Lou P, Lesniewski R and Henkin J: Paclitaxel at ultra low concentrations inhibits angiogenesis without affecting cellular microtubule assembly. Anticancer Drugs 14: 13-19, 2003.

26. Zhang M, Tao W, Pan S, Sun X and Jiang H: Low-dose metronomic chemotherapy of paclitaxel synergizes with cetuximab to suppress human colon cancer xenografts. Anticancer Drugs 20: 355-363, 2009

27. Bouis D, Hospers GA, Meijer C, Molema G and Mulder NH: Endothelium in vitro: a review of human vascular endothelial cell lines for blood vessel-related research. Angiogenesis 4: 91-102, 2001

28. Moore M, Hirte HW, Siu L, Oza A, Hotte SJ, Petrenciuc O, Cihon F, Lathia C and Schwartz B: Phase I study to determine the safety and pharmacokinetics of the novel Raf kinase and VEGFR inhibitor BAY 43-9006, administered for 28 days on/ 7 days off in patients with advanced, refractory solid tumors. Ann Oncol 16: 1688-1694, 2005.

29. Brada M, Judson I, Beale P, Moore S, Reidenberg P, Statkevich P, Dugan M, Batra V and Cutler D: Phase I dose-escalation and pharmacokinetic study of temozolomide (SCH 52365) for refractory or relapsing malignancies. Br J Cancer 81: 1022-1030, 1999.

30. Malingre MM, Terwogt JM, Beijnen JH, Rosing H, Koopman FJ, van Tellingen O, Duchin K, Huinink WW, Swart M, Lieverst J and Schellens JH: Phase I and pharmacokinetic study of oral paclitaxel. J Clin Oncol 18: 2468-2475, 2000.

31. Marty M, Fumoleau P, Adenis A, Rousseau Y, Merrouche Y, Robinet G, Senac I and Puozzo C: Oral vinorelbine pharmacokinetics and absolute bioavailability study in patients with solid tumors. Ann Oncol 12: 1643-1649, 2001.

32. Sessa C, Zucchetti M, Cerny T, Pagani O, Cavalli F, De Fusco M, De Jong J, Gentili D, McDaniel C, Prins C, Schacter L, Winograd B and D'Incalci M: Phase I clinical and pharmacokinetic study of oral etoposide phosphate. J Clin Oncol 13: 200-209, 1995. 